\title{
Very early diagnosis of HIV infection in newborn at day 0-day 3 on DBS in Cambodia
}

\author{
Sopheak Ngin*1, Sim Kruy Leang, ${ }^{1,2}$, Chhunly Kong1,3, Sethikar $\operatorname{Im}^{1,2}$, \\ Vannith Lim ${ }^{1,2}$, Meng Ly Ek ${ }^{1,2}$, Denisa Augustinova ${ }^{1,4}$, Kanal Koum, ${ }^{1,5}$ \\ Christine Rouzioux ${ }^{1,6}$ and Eric Nerrienet ${ }^{1}$
}

Address: ${ }^{1}$ Institut Pasteur, Phnom Penh, Cambodia, ${ }^{2}$ Calmette Hopsital, Phnom Penh, Cambodia, ${ }^{3}$ Chey Chaum Neas Hospital, Takamao, Kandal province, Cambodia, ${ }^{4}$ Magna Children at Risk, Phnom Penh, Cambodia, ${ }^{5}$ NMCHC Hospital, Phnom Penh, Cambodia and ${ }^{6}$ EA 3620 , Université Paris-Descarte, CHU Necker-Enfants Malades, Paris, France

* Corresponding author

from Fifth Dominique Dormont International Conference. Mother-to-child transmitted viral diseases: from transmission to children care Paris, France. 26-28 March 2009

Published: 22 July 2009

Retrovirology 2009, 6(SuppI I):OI0 doi:I0.II86/1742-4690-6-SI-OIO

This abstract is available from: http://www.retrovirology.com/content/6/SI/OIO

(c) 2009 Ngin et al; licensee BioMed Central Ltd.

\section{Background}

In resource constrained settings where prevention of mother to child transmission of HIV-1 (PMTCT) programs are in place, the proportion of residual in utero transmission (rIUT) versus peri partum transmission (PPT) is unknown and the morbidity/mortality related, or not, to MTC transmission of HIV-1, within the first 6 weeks of life, poorly documented.

\section{Main objective}

To assess the feasibility and the contribution of the very early diagnosis on Dried Blood Spot (DBS), conducted at day 0 -day 3 of age in improving the medical care of HIV1 exposed newborn within the first 6 weeks of life.

\section{Methods}

Very early diagnosis was explained and proposed, before and/or after delivery, to HIV positive mothers delivering at Calmette and hospitals and health centers supported by Magna Children at Risk (NMCHC, Chey Chumneas Hospital and 3 Municipality Health Centers). A first negative HIV-DNA negative DBS at day 0-day 3 was followed up by a second DBS at W6. HIV-DNA positive DBS at d0-d3, or at week 6 were followed up by a venipuncture as soon as possible for HIV-RNA quantification (Kit G2 ANRS) and CD4 count.

\section{Preliminary results}

Heel prick blood specimens were spotted on DBS for 272 newborns (ratio $\mathrm{M} / \mathrm{F}=1.3$ ) at $\mathrm{d} 0-\mathrm{d} 3$. HIV DNA was detected in 3 of 272 babies (rIUT rate: 1.1\%). One of them died before week 6 . The two others presenting detectable HIV-1 RNA viral loads at week 6 (6.4 and $6.9 \log _{10}$ copies/ ml with CD4 at $19 \%$ and $21 \%$, respectively) started first line ARV regimen and became HIV-1 RNA undetectable after 10 and 4 months of treatment. Among the 269 HIVDNA negative newborn at d0-d3, 228 (84.5\%) have been already seen at week 6 for virological confirmation, 23 are still waiting for the visit of the week 6,14 were lost of follow up and 4 died without any AIDS clinical symptoms. 226 of 228 DBS were confirmed HIV-DNA negative at week 6 whereas 2 infants became HIV-DNA positive (PPT rate: $0.8 \%$ ). Both were confirmed HIV-RNA positive two weeks later (5.8 and $6.2 \log _{10}$ copies/ml with CD4 at 33\% and 26\%, respectively) and will soon begin their ARV treatment.

\section{Discussion}

The rIU and PP transmission rates were low in this study ( $1.1 \%$ and $0.8 \%$ respectively). 5 new born were diagnosed HIV infected. One died before W6, and 2 already started ARV treatment. Further investigations are undergoing to understand why 14 newborn were lost of follow up. These preliminary results demonstrate the feasibility of a mini- 
mally invasive very early diagnosis, done shortly after birth. The small amount of blood required, the ease of collection, storage, and transport of samples, and the low cost of the test make it ideal for HIV-1 testing of infants in remote maternities in Cambodia.

Publish with Bio Med Central and every scientist can read your work free of charge

"BioMed Central will be the most significant development for disseminating the results of biomedical research in our lifetime. " Sir Paul Nurse, Cancer Research UK

Your research papers will be:

- available free of charge to the entire biomedical community

- peer reviewed and published immediately upon acceptance

- cited in PubMed and archived on PubMed Central

- yours - you keep the copyright 